Relations industrielles

Industrial Relations

\title{
Decentralized Bargaining in a Globalizing Industry
}

The Automotive Assembly Industry in Australia

La négociation décentralisée dans une industrie qui se mondialise

Le cas de l'industrie de l'automobile en Australie

Negociación descentralizada en una industria en vías de globalización

\section{La industria de ensamblaje automotriz en Australia}

\author{
Russell D. Lansbury, Chris F. Wright et Marian Baird
}

Volume 61, numéro 1, hiver 2006

URI : https://id.erudit.org/iderudit/013721ar

DOI : https://doi.org/10.7202/013721ar

Aller au sommaire du numéro

\section{Éditeur(s)}

Département des relations industrielles de l'Université Laval

\section{ISSN}

0034-379X (imprimé)

1703-8138 (numérique)

Découvrir la revue

Citer cet article

Lansbury, R. D., Wright, C. F. \& Baird, M. (2006). Decentralized Bargaining in a Globalizing Industry: The Automotive Assembly Industry in Australia. Relations industrielles / Industrial Relations, 61(1), 70-92.

https://doi.org/10.7202/013721ar

\section{Résumé de l'article}

Cet essai cherche à vérifier de quelle façon le secteur de l'assemblage des automobiles en Australie a réagi à la double pression de la mondialisation croissante et de la négociation à l'échelle de l'entreprise. L'industrie de la fabrication automobile a joue un rôle majeur dans l'economie australienne et, de plus, elle represente l'une des industries d'importation les plus importantes. Le secteur inclut plusieurs centaines de fournisseurs de pieceses et quatre constructeurs automobiles: possédés par des Japonais. La nature compétitive croissante de l'industrie automobile à l'échelle mondiale, les profits qui s'effritent et une diminution du ratio des exportations sur les importations dans l'industrie australienne ont incité les gouvernements, les manufacturiers et les syndicats à concevoir des façons de rendre l'industrie plus efficace.

Un changement majeur qui a affecté l'industrie australienne de l'automobile au cours de la dernière décennie fut le glissement d'un système fortement centralisé de relations industrielles vers une forme plus décentralisée de négociation collective sur la base de l'entreprise. Cette dernière implique une négociation directe des conditions d'emploi et des salaires entre les employeurs et leurs employés, qui est officialisée par des conventions collectives à l'échelle de l'entreprise. Le caractère fortement syndiqué de l'industrie australienne de l'automobile implique que les syndicats négocient des ententes au nom des salariés non syndiqués dans l'entreprise.

D'un côté, on peut s'attendre à ce que la mondialisation introduise un degré de convergence plus élevé entre les manufacturiers. D'un autre côté, la négociation sur la base de l'entreprise peut entraîner une divergence plus grande entre les sociétés et, par conséquent, contribuer à une variation intra-industrie plus prononcée. De plus, des facteurs institutionnels nationaux peuvent être perçus comme un frein aux influences de la mondialisation et ils peuvent façonner la nature des résultats des relations du travail.

En termes d'organisation du travail, il existe une compréhension commune du concept, sinon de la pratique, de la production « allégée » (lean production). Trois des quatre constructeurs mettent de l'avant des stratégies de production allégée; cependant, il existe des différences en pratique quant à l'ampleur de l'application de ces principes chez les quatr constructeurs. Cest particulierement le cas lorsqu' on considere le travail déquipe, où les differences sont importantes au plan de la composition et des objectifs des equipes. Dans trois des quatre societes, les modes de dotation en personnel ont jusqu'à récemment. C'est à la société Mitsubishi, l’acteur le plus pauvre dans ce marché, nù la divergence la plus grande au plan de la dotation s'est produite, alors que les syndicats abandonnaient la permanence à une agence de recrutement en retour d'une sécurité d'emploi et de marché pour les autres employés. La formation professionnelle reflète l'influence forte du secteur, avec des normes de formation communes pour l'industrie et
des salaires payés par toutes les entreprises selon les compétences. Cependant, c'est au plan de la rémunération globale que d'autres différences se produisent et, encore là, c'est la société Mitsubishi qui fait bande à part. Les effets de la négociation à l'échelle de l'entreprise chez les salariés de Mitsubishi ont commencé à décliner vers la fin des années 1990 et ils ne sont pas revenus au niveau atteint par les trois autres sociétés. En termes de gouvernance d'entreprise, le syndicat a de nouveau maintenu une approche homogène et raisonnable, quoique cela n'apparaisse pas de la même manière dans les accords d'entreprise.

La convergence s'est donc produite dans les systèmes de production, dans la formation et dans la gouvernance d'entreprise, alors que la divergence entre les quatre constructeurs est apparue dans les pratiques de dotation et de rémunération. La concurrence accrue des competiteurs d'outre-mer a ete invoquee en guise de support aux reformes des relations du travail, mais la direction qu'a pris ce changement a été influencée par des décisions à la portée de la main des employeurs et des syndicats. En effet, le recours à l'emploi précaire et une disposition touchant l'excédent de main-d'oeuvre sont devenues les principales stratégies retenues par les sociétés pour atténuer les pressions concurrentielles de la mondialisation sur les chez les quatre constructeurs, des facteurs d'ordre institutionnel à l'échelle du pays sont venus freiner l'apparition d'une divergence plus prononcée. Le reliquat de la centralisation, la force des syndicats du secteur et même une coordination des négociations chez les employeurs du secteur ont contribué au maintien d'une continuité eu égard à la reconnaissance syndicale et au support apporté au membership. Il existe également des similitudes entre les sociétés dans les domaines des heures de travail, de la formation professionnelle et des dispositions relatives au surplus de main-d'oeuvre.

L'avenir à long terme de l'industrie de l'automobile en Australie demeure aléatoire, du à la concurrence de l'importation, à des changements dans la politique gouvernementale sur la protection des tarifs et aux fluctuations du taux de change $d u$ dollar australien. Egalement, l'incertitude persiste quant à savoir si les societés mondialisees sont disposées à investir en longue période dans le secteur domestique de l'automobile. Étant donné la petitesse du marché australien, la survie à long terme de l'industrie dépend aussi des stratégies mises de l'avant par les entreprises en vue de la production de véhicules de classe mondiale et pour l'obtention d'un accès aux marchés d'outre-mer pour leurs produits. Comme ce fut le cas à ce jour, la négociation sur la base de l'entreprise continuera à demeurer un indicateur du degré auquel les sociétés chercheront à integrer les relatios du raval a de

industrielles dans une industrie de plus en plus mondialisée demeure une inconnue.
Tous droits réservés (C) Département des relations industrielles de l'Université Laval, 2006
Ce document est protégé par la loi sur le droit d'auteur. L'utilisation des services d'Érudit (y compris la reproduction) est assujettie à sa politique d'utilisation que vous pouvez consulter en ligne.

https://apropos.erudit.org/fr/usagers/politique-dutilisation/ 


\title{
Decentralized Bargaining in a Globalizing Industry
}

\section{The Automotive Assembly Industry in Australia}

\author{
RUSSELl D. LANSBURY \\ Chris F. Wright \\ MARIAN BAIRD
}

This paper examines the impact of enterprise bargaining on employment relations practices in the Australia automotive assembly sector in the context of the globalization of the industry. While there has been convergence towards lean production principles among the four auto assemblers, arising from global trends, there has also been divergence resulting from enterprise bargaining, among other variables. Strong similarities are apparent between the companies in areas such as work organization, skill formation and enterprise governance, whereas there are differences in remuneration and staffing practices. However, it remains to be seen whether decentralized bargaining will continue to yield greater differentiation in employment relations among the automotive manufacturers in an increasingly globalized industry.

The automotive manufacturing industry has played an important role in the development of the Australian economy. It accounts for nearly six per cent of the total value added for manufacturing, making it one of the largest

- Lansbury, R., Work and Organisational Studies, School of Business, University of Sydney, Australia, r.lansbury@econ.usyd.edu.au

- Wright, C. F., Work and Organisational Studies, School of Business, University of Sydney, Australia, c.wright@econ.usyd.edu.au

- BAIRD, M., Work and Organisational Studies, School of Business, University of Sydney, Australia,m.baird@econ.usyd.edu.au

- This paper is part of a project on Globalization and Employment Relations in Autos and Banking (GERAB) with contributing researchers from the United States, Europe and Asia. The authors wish to acknowledge the assistance of the Australian Research Council which awarded them a Discovery Grant to fund this project. 
manufacturing sectors, and is among Australia's most significant export industries (DISR, 2005). The sector comprises several hundred component suppliers and four vehicle assemblers-Ford, GM-Holden, Mitsubishi and Toyota - the first two being American-owned and the latter two being Japanese-owned. GM-Holden and Mitsubishi have assembly plants located in Adelaide, South Australia, where manufacturing has historically been a centrepiece of the local economy. Ford and Toyota's assembly operations are situated in Melbourne, Victoria, where the economy is more diversified. GM-Holden also has an engine manufacturing plant in Melbourne.

The increasingly competitive nature of the automotive industry on a global scale, declining profits and a decrease in the ratio of exports to imports in the Australian industry have prompted governments, manufacturers and unions to examine ways to make the industry more efficient. The dismantling of tariffs by governments over the past two decades has exposed local automotive producers to greater import competition. One consequence has been Australian manufacturers shifting the focus away from the local market and towards overseas markets, particularly the Middle East. Nonetheless, while the value of exports by Australian producers has increased over the past decade, this pales in significance compared to the growth in imports (see Table 1).

TABLE 1

Value and Growth of Automotive Imports and Exports for Selected Years (in \$B Australian)

\begin{tabular}{lccccc}
\hline & 1990 & 1993 & 1996 & 1999 & 2002 \\
\hline Imports & 5.45 & 7.36 & 10.69 & 14.96 & 18.54 \\
Exports & 1.04 & 1.47 & 2.26 & 3.25 & 4.83 \\
\hline
\end{tabular}

Source: Department of Industry, Science and Resources (DISR). 2000. Key Automotive Statistics 1999. Canberra: Commonwealth of Australia, tables 18 and 22; Department of Industry, Tourism and Resources (DITR). 2003. Key Automotive Statistics 2002. Canberra: Commonwealth of Australia, tables 14 and 18.

The relative share of the vehicle market in Australia since the early 1990s has declined for all local assemblers except Toyota, which accounted for almost 25 per cent of all vehicles sold in 2002. The proportion of locally produced vehicles sold in Australia has declined steadily from 68 per cent in 1991 to 41 per cent in 2003. The decline in Mitsubishi's share of the local market has been so severe that its long-term viability (under its new owner Daimler Chrysler) continues to be uncertain and in 2004, one of its plants was closed. Ford and GM-Holden have also witnessed significant reductions in their share of the Australian vehicle market (see Table 2). 
TABLE 2

Total Market Share for All Vehicles Sold for Selected Years (\%)

\begin{tabular}{lcccc}
\hline & 1993 & 1996 & 1999 & 2002 \\
\hline Toyota & 21.9 & 18.6 & 19.5 & 24.4 \\
GM-Holden & 17.4 & 19.2 & 19.7 & 12.7 \\
Ford & 20.9 & 20.3 & 16.1 & 12.6 \\
Mitsubishi & 13.7 & 9.4 & 8.9 & 7.4 \\
Other Imported & & & & \\
Vehicles & 26.1 & 32.5 & 35.8 & 42.9 \\
\hline Total & 100 & 100 & 100 & 100 \\
\hline
\end{tabular}

Source: DISR. 2000. Key Automotive Statistics 1999. Canberra: Commonwealth of Australia, table 3; DISR. 2001. Key Automotive Statistics. Canberra: Commonwealth of Australia, table 3; DITR. 2002. Key Automotive Statistics 2001. Canberra: Commonwealth of Australia, table 6; DITR. 2003. Key Automotive Statistics 2002. Canberra: Commonwealth of Australia, table 6.

Another important change which has affected the Australian automotive industry during the past decade has been the shift from a predominately centralized system of industrial relations to a more decentralized form of enterprise bargaining. This involves direct negotiation between employers and their employees. In the auto industry, most employees are unionized, and the unions negotiate enterprise agreements on their behalf. Enterprise bargaining agreements (EBAs) are underpinned by awards, which are generally established on an occupational or industry-wide basis.

This paper examines how the auto assembly sector has responded to the dual pressures of increasing globalization and decentralized bargaining. The paper begins by discussing the methodological approach used in analyzing changes in the Australian automotive sector. The literature review indicates how this research relates to contemporary debates surrounding variations in employment relations. The focus of our paper examines changes in employment relations among the four Australian automotive assemblers focusing on the themes of bargaining structures, work organization, staffing, skill formation, wages and remuneration, and enterprise governance. In conclusion, the impact on employment relations of decentralized bargaining at the national level on a globalize industry is evaluated. 


\section{METHODOLOGY}

At the time of writing, awards were used to set minimum standards for a maximum of 20 specific employment matters as defined by the Workplace Relations Act 1996. Enterprise agreements, which exist in conjunction with awards, are not allowed to undercut the provisions contained in an award, but can cover a much broader range of provisions. Unlike awards, which can be amended at any time by agreement between the parties or through arbitration by the Australian Industrial Relations Commission (AIRC), enterprise agreements must be renegotiated at least every three years. Rather unusually, the awards applying to the automotive assembly sector are in essence "enterprise awards", with each company having its own award.

In conducting this study, a content analysis was undertaken of all of the EBAs that were certified by the AIRC between 1992 and 2004 for the Ford, Toyota, GM-Holden and Mitsubishi assembly plants, the three Adecco agreements that have been certified since 1999 covering Mitsubishi employees, as well as the enterprise awards of the four automotive assemblers since 1988. By examining the awards applicable to the automotive assembly sector as well as enterprise agreements, this paper seeks to avoid the criticism of Bray and Waring (2005) that studies focusing on labour regulation have tended to disregard the "horizontal complexity" of regulatory instruments. Such analysis is necessary as the existence of dual regulation through awards and agreements is fundamental in understanding the rather complicated nature of employment regulation in the Australian automotive assembly sector. Figure 1 shows the complexity of regulation in the industry by listing each award and enterprise agreement for each company by year since 1992 .

\section{FIGURE 1}

\section{Duration on Automotive Assembly Sector EBAs, Since 1992}

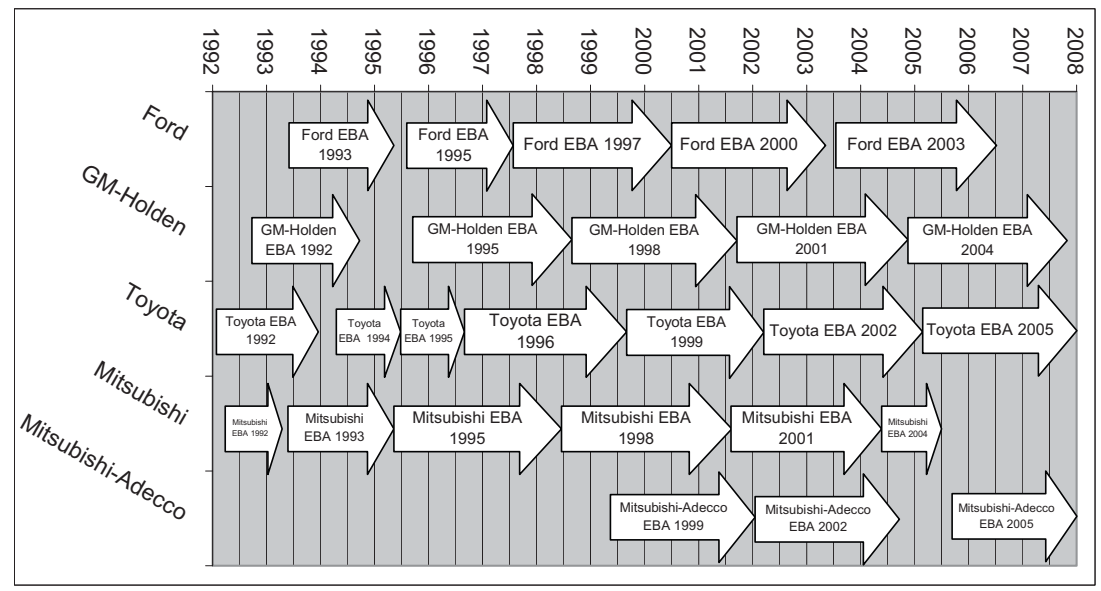


The analysis involved examining the clauses of agreements and awards according to the framework used in a previous study (cf. Kitay and Lansbury, 1997). Some minor adjustments were made to this framework in accordance with structures associated with enterprise bargaining in Australia. This resulted in the content analysis being structured around five broad themes, each of which encompasses various sub-categories: "work organization" entails job structures and demarcation, the structure of teams and working hours; "staffing arrangements" includes methods of staffing adjustment, such as redundancy and precarious forms of employment; "skill formation" covers themes including industry standards on skills and training; "wages and remuneration" encompasses themes such as wage outcomes, wage determination and performance-based pay arrangements; and "enterprise governance" covers such themes as union involvement, committees, consultation arrangements and other forms of employee involvement.

The analysis of enterprise agreements and awards was supplemented by over 40 in-depth interviews with management representatives, full-time union officials, union delegates, team leaders and rank-and-file employees from the automotive assembly sector. A number of the people that were interviewed later provided feedback on our preliminary findings.

\section{REVIEW OF THE LITERATURE}

A number of studies have examined continuity and change in employment relations relevant to our research. Debates about whether globalization results in convergence or divergence in systems of employment relations stem from the original work of Kerr et al. (1960), who argued that industrialization - or more specifically, technology and market competition arising from industrialization-resulted in a convergence of national systems of industrial relations at an institutional level around "principles of pluralistic industrialism". In response to Kerr et al., a plethora of studies sought to either extend or challenge their convergence thesis (cf. Bamber, Lansbury and Wailes, 2004). A number of these studies have been specific to the automotive sector.

In an influential book on the auto industry, The Machine that Changed the World, Womack, Jones and Roos (1990) argued that international competitive pressures would lead to convergence on "best practice" or "the one best way", irrespective of the company's ownership or national identity. In their view, the lean production system developed by the Toyota Motor Company not only transformed the method of producing motor vehicles, but also the means by which employees were managed. ${ }^{1}$ Any firm that

1. Lean production is based on a system developed by the Toyota Motor Company to create a more flexible, demand-oriented process. Its principles include an integrated 
failed to adopt lean production would fall by the wayside in an increasingly competitive world market. Yet critics of the study by Womack, Jones and Roos argued that employment practices are shaped not in a deterministic fashion by a single global technological or economic imperative but by a multiplicity of factors.

Kochan, Lansbury and MacDuffie (1997) found that while lean production principles were diffused to automotive plants around the world, the patterns of adoption were not of a single character. Rather, important variations reflected the effects of institutional and cultural forces as well as differences in the strategies and the power of the parties involved. From their case studies, Kochan, Lansbury and MacDuffie reported a trend towards convergence across countries combined with divergence across and within companies. Hence, although convergence existed around matters of principle (such as the desirability of lean production), diversity prevailed in the ways these were translated into practice.

Based on their research into automotive and telecommunications industries, Katz and Darbishire (2000) coined the term "converging divergences" to describe a common set of changes in employment relations taking place in a range of developed market economies, such as decentralization of bargaining and individualization of relations between employers and employees. They attributed particular importance to the shared experience of increasing diversity in employment relations. However, they also argued that institutional differences across countries resulted in variations in the distribution of employment relations patterns in each country. Despite evidence of divergence between national employment relations systems, Katz and Darbishire (2000: 281) also emphasized that, "the persistence of sizeable country differences in the relative mix of various employment patterns, and the role that national level institutions play in shaping that mix, suggest a continuing influential role for national employment-related institutions".

Similarly, Locke (1992) attributed national socio-economic conditions and the politics of strategic choice - that is, the ways that actors such as employers and unions are able to shape employment relations in response to industrial change-as factors that explain intra-national variation in employment relations. Specifically, Locke argues that the relative power and organizational capacities of the parties, the ideological dispositions of managers and union leaders and the influence of other local factors and institutions will have an effect on the response of employers and unions and other actors to industrial change.

simple piece production flow with small batches made just-in-time, an emphasis on defect prevention rather than rectification, team-based work organization and close buyersupplier relationships. 
In the context of previous research on whether external market competition results in convergence or divergence of employment relations systems, this paper seeks to explain how employment relations in the Australian automotive assembly sector have changed, both between and within firms, over time. In doing so, we attempt to isolate the extent to which the strategic choices available to employers, unions and governments, as well as institutional and structural factors, have shaped the direction that this change has taken.

\section{INSTITUTIONAL FACTORS}

Since 1991, both Labor and Liberal-National governments have encouraged enterprise bargaining, marking a major shift away from a more centralized approach to employment relations (cf. Kitay and Lansbury, 1997). However, there is still an element of external regulation in the automotive sector and more generally, across the industrial relations system. The AIRC, a tribunal established by the Commonwealth Government at the turn of the twentieth century (then under a different name), continues to have the power to settle disputes through conciliation and arbitration, to certify enterprise agreements and to establish minimum standards across the workforce (cf. Bray et al., 2005). ${ }^{2}$ The continuing role of the AIRC has meant that the legacy of external regulation continues to have an influence in the automotive assembly sector, as do other "third parties" such as trade unions.

Over the last two decades, there has been a significant decline in the proportion of workers in Australia that are members of trade unions, falling from 49 per cent in 1982 to 23 per cent in 2002 (Australian Bureau of Statistics, cited in Bray et al., 2005: 202). Despite this decline, unions in the automotive sector have maintained high levels of membership, which has meant that they continue to wield considerable power in automotive employment relations. Among the vehicle producers (and large component suppliers) there is almost 100 per cent union coverage below the managerial levels of the workforce.

The trade union that covers most employers in the automotive industry is the Australian Manufacturing Workers Union (AMWU), which was augmented in 1995 through an amalgamation of several manufacturingbased unions. While there are several other unions covering clerical

2. However, the influence of the AIRC looks set to be reduced after the Commonwealth Government introduced the WorkChoices legislation in 2005 which seeks to overhaul existing regulatory arrangements and curtail the power of third parties over the employment relationship (Ellem et al., 2005). 
workers and electrical tradespersons, the AMWU represents about 90 per cent of unionized employees, with its Vehicle Division covering around 70 per cent of waged employees in the sector. The sentiment among employees interviewed for this study is that there is widespread support for the AMWU, although some members expressed the view that their union should have pressed companies harder to raise skill levels and expand career opportunities for the workforce. There also remain differences between the Vehicle and Metal divisions of the AMWU over the issue of allowing production workers to move into maintenance and trades areas of work. Disputes in the industry have been increasing since the late 1990s as employers seek to achieve greater labour flexibility and productivity improvements through enterprise bargaining (see Table 3). Despite this, according to management and union officials in the industry, relations between the parties are generally amicable.

TABLE 3

Number of Disputes and Employees Involved in Industrial Disputes in the Automotive Industry in Australia, 1991-2001

\begin{tabular}{|c|c|c|c|c|c|c|}
\hline & 1991 & 1993 & 1995 & 1997 & 1999 & 2001 \\
\hline Number of Disputes & 10 & 8 & 10 & 3 & 18 & 19 \\
\hline $\begin{array}{l}\text { Number of Employees directly } \\
\text { or indirectly involved }(000 \mathrm{~s})\end{array}$ & 5 & 13 & 10 & 10 & 21 & 16 \\
\hline
\end{tabular}

Source: Productivity Commission. 2002. Review of Automotive Assistance: Inquiry Report. Canberra: Commonwealth of Australia, 253.

Although enterprise bargaining was not formally encouraged by government until 1991, the vehicle assembly sector is unique in that a form of quasi-enterprise bargaining was introduced as early as 1973 when an industry-wide award was abandoned and replaced with enterprise awards for each of the main assemblers. Despite this leading to some divergence in the employment relations outcomes of the four automotive assemblers, as may be assumed, many similarities remained until enterprise bargaining was formally introduced.

Through the Federation of Vehicle Industry Unions, the AMWU and the other unions covering automotive workers coordinate their enterprise bargaining strategies and industrial campaigns. This has led to some uniformity in the outcomes of enterprise agreements among the four automotive assemblers, leading the government to allege that unions have been engaging in "pattern bargaining" (cf. DEWR, 2002). There is also a large degree of coordination among the bargaining strategies of the automotive manufacturers. While this coordination is not as tightly organized as it is 
between the unions, the human resource executives of GM-Holden, Toyota, Ford and Mitsubishi meet regularly to discuss their bargaining strategies but without disclosing details, particularly when one of the companies is in the process of bargaining a new collective agreement. They also keep a close eye on the bargaining outcomes of their competitors.

\section{WORK ORGANIZATION}

Largely due to the dominance of Toyota and its success in pioneering "lean production", all of the companies operating assembly plants in Australia have adopted a variant of the Toyota Production System (cf. Kochan, Lansbury and MacDuffie, 1997). Each company has created its own hybrid system of production based on a combination of their own management philosophy and elements of lean production. The introduction of new production systems in assembly plants has had significant implications for the way in which work is organized and how decisions are made about changes in the workplace.

Senior managers among the ranks of its competitors acknowledge that Toyota's success in implementing lean production means that it continues to set the benchmark for the industry. Indeed, Toyota's enterprise agreements deal with provisions relating to production more comprehensively than the other assemblers, with its EBAs noting that formal, accredited training is provided to familiarize employees with the Toyota Production System. Ford and GM-Holden are also quite detailed in their discussion of production system arrangements, but this is not the case with Mitsubishi's EBAs and awards, which are reflective of their status as having the least automated production arrangements of the four assemblers.

Despite the long-established Toyota Production System, one union official claimed that the Ford had the "leanest" production system of the four assemblers, and a number of Toyota's managers also conceded that its production techniques could be leaner. Greater use of technology and the introduction of "leaner" production methods have increased efficiency and production output across the four assemblers and raised the skill levels of employees. However, there is evidence from employees that the increased speed of the production line has had negative implications for work intensification and raised concerns about the potential elimination of jobs.

There have been significant changes to job structures and demarcation in the automotive industry in recent years: from 240 job classifications in the award, to only three non-trade levels and six trade levels. These reforms came about not through enterprise bargaining but rather through a government-led initiative in the late 1980s to restructure awards, which 
interestingly was consistent with lean production principles. As a result of this process, all automotive assembly sector awards since 1988 have contained new classification structures setting out the job requirements in terms of competencies, qualifications, general duties and responsibilities for all non-salaried occupations, as reflected in the Toyota Award. Substantial efforts have been made in recent years to reduce demarcations between trade and non-trade employees. While a number of managers claim that there is greater scope for production workers to become trades workers, problems have started to re-emerge over the delineation of duties between trades workers and technicians.

While the Toyota-style lean production system has been introduced in at least three of the four assemblers, consistent with earlier findings (cf. Bamber and Lansbury, 1997), there is variation as far as to the way that team work, a key component of lean production, has been implemented. It is difficult to precisely define differences in the team systems of the four companies simply from the descriptions given in their EBAs, but field visits and interviews add much more depth to the picture. GM-Holden has implemented "work groups", which follow a much more inclusive and democratic European model of workplace structuring, as distinguished from the "team work" model, used in some overseas General Motors operations, which is characterized by a more American and Japanese-based approach (Murakami, 1999: 117-120). Ford has introduced "natural work groups" and "integrated manufacturing teams", which involve non-trade and trade employees working together as part of a cohesive work group. According to Toyota's enterprise agreements, team work is included as part of the continuous improvement/kaizen and Toyota Production and Management Systems processes. While production at Mitsubishi is organized according to teams, employees claim that the effective utilization of team work is only operative to a limited degree.

The Productivity Commission (1996: 117) claimed that "employees in many of the firms are now operating in small self-managed teams that are proving to be more productive than previous arrangements due to the higher motivation of employees". However, according to a senior union official, the teams in some plants were more likely to lead to work intensification and less employee autonomy than the team systems used elsewhere. There was a mixed response from managers in regards to the success of teams, with some claiming that there was still much scope for progress, and others claiming that teams were implemented inconsistently across the production line. According to one manager, teams on the assembly line have been ineffective and were gradually deteriorating, causing management to reconsider their usefulness. Yet a number of employees expressed confidence in the effectiveness of the team system and felt that it provided 
opportunities for participation in decision-making. Conversely, workers at one plant referred to the team systems as "unnatural work groups" because the company allocated each employee to a particular group and appointed group leaders. One employee said that this resulted in peer surveillance around issues such as absenteeism and quality.

The hours of work provisions are very similar across the four auto assemblers and there have been only minor variations in these conditions over recent years. A 38-hour week and a 19-day month are standard throughout the industry, although Mitsubishi implemented a nine-day fortnight in designated parts of their operations. There are also minor differences between the companies in the provisions for employees to take off flexible rostered days. A number of recent enterprise agreements allow for the possibility of introducing more flexible shift arrangements through consultation with unions and employees. GM-Holden capitalized on this arrangement by introducing a third shift, when there was high demand for vehicles, thereby allowing the company to maintain continuous 24 hour production.

\section{STAFFING PRACTICES}

There has been a decline in the number of workers employed in the automotive industry since the early 1990s, within the vehicle manufacturing sector and across the industry as a whole (see Table 4). The decision by Nissan to abandon its Australian operations in 1992 and the recent closure of one of Mitsubishi's plants have contributed to this decline, but falling employment numbers is indicative of the increasing pressure on the Australian industry from import competition. One of the main ways that automotive manufacturers have sought to alleviate such pressures is through greater staffing flexibility, the use of non-full-time employment and reductions in employment levels. According to employees and managers, there is some antipathy towards the union from its members for "giving too much away" by allowing Mitsubishi to insert an "implementation of change" clause in its 2001 agreement. It was claimed that management at the company now has too much power to implement change, such as staffing flexibility.

In Australia, generally there has been a growth in the utilization of contingent or precarious forms of employment since the introduction of award restructuring and decentralized bargaining in the late 1980s and the early 1990s. This was subsequently reinforced through measures enacted by the Liberal/National government during the mid-1990s aimed at stimulating employment growth (Wailes and Lansbury, 1997: 5). While the number of full-time employees as a proportion of the total workforce stands at around 70 per cent, this figure remains above 90 per cent for automotive industry. 
TABLE 4

Employment in the Automotive Industry in Australia

\begin{tabular}{lcccc}
\hline & $1990 / 91$ & $1993 / 94$ & $1996 / 97$ & $1999 / 00$ \\
\hline Motor Vehicle Manufacturing & 27,500 & 22,559 & 20,330 & 16,519 \\
Auto Component Manufacturing & 23,900 & 20,841 & 21,868 & 22,422 \\
Other Areas of Auto Manufacturing & 11,900 & 10,515 & 12,054 & 15,547 \\
Total & 63,300 & 53,915 & 54,252 & 54,488 \\
\hline
\end{tabular}

Source: DISR. 2000. Key Automotive Statistics 1999. Canberra: Commonwealth of Australia, table 27; DITR. 2003. Key Automotive Statistics 2002. Canberra: Commonwealth of Australia, table 22.

Recent measures introduced by three of the major companies, however, have the potential to modify this trend.

Mitsubishi introduced a new employment arrangement in the late 1990s when it entered into agreement with labour hire firm Adecco to enable the company to hire "variable temporary labour". Adecco thus became the employer of these workers rather than Mitsubishi. This strategy was enacted by Mitsubishi after the company warned the AMWU that unless labour flexibility was able to be utilized, the parent company might close its Australian operations. Mitsubishi's arrangement with Adecco enabled it to introduce a form of numerical flexibility not available to the other manufacturers. Adecco hires workers out to other industries when they are not needed at Mitsubishi so that they continue to receive full pay. According to one Mitsubishi manager, this arrangement is "a classic case of where enterprise bargaining has been extremely beneficial for the company and the workforce". The 1998 Mitsubishi agreement provided for a 15 per cent ratio of the total permanent workforce to be "variable temporary labour" (VTL). The 2001 EBA increased the maximum ratio of VTL in proportion to the total permanent workforce to 20 per cent, and redefined VTL to include "variable temporary casual labour" engaged by the hour and "variable temporary labour weekly hire".

The 2005 Mitsubishi-Adecco agreement went further in pursuing innovative forms of flexibility. The agreement specifies that casual loading would be withheld from employees, who would receive an accrued loading payment either at the end of their period of engagement with Adecco, or at the request on the employee in consultation with the company. This arrangement would potentially overcome the problem of casual employees not having the paid leave entitlements of permanent employees. The agreement also gave variable temporary casual employees the option of converting 
to weekly hire status on either a full-time or part-time basis after being engaged for a continuous 12 month period.

While Mitsubishi is the only assembler to have such an arrangement with a labour hire company, Toyota has introduced a system whereby contract workers can be hired when a permanent worker takes leave of absence for more than four weeks. Furthermore, Toyota has been able to use its most recent EBA to gain more flexibility by hiring all production workers on a probationary period for the first six months of employment, after which time they are either made permanent or their employment ceases. GM-Holden has been able to use contractors for maintenance work but, like Toyota, this is not arranged through a labour hire company. GM-Holden has also increased the number of its "fixed term employees" in recent years and has been able to more extensively utilize part-time workers through its most recent enterprise agreement.

With the reduction of employment in the auto assembly industry over the past decade, provisions for redundancy and other job security issues have been increasingly prevalent in enterprise agreements. Indeed, job and income security have been major issues of contention in recent rounds of EBA negotiations. However, some union officials argue that the gains in redundancy provisions reflect many workers' preference to take redundancy pay rather than fight to retain their jobs. For example, the union officials claim that many workers have been willing to accept redundancy following the recent closure of one of the two Mitsubishi plants rather than seek relocation to the company's remaining plant.

This appears to be part of a broader strategy by the unions of shifting their focus from extending employees' entitlements to protecting existing conditions through greater job security. While wages undoubtedly continue to be important, as evidenced by wage gains in recent bargaining rounds at GM-Holden and Toyota, the growing significance of job security to workers in the industry is not surprising given the vulnerability of automotive assemblers in Australia to reductions in government protection and greater exposure to the global market. Redundancy packages were introduced by all of the companies in the early 1980s, but while the provisions relating to redundancy in the various enterprise agreements contain similarities, they are by no means uniform. The amount of redundancy pay and the options available for issues such as payment of entitlements, non-monetary benefits and alternatives to redundancy have changed notably over the past decade, and variation continues between the firms on these issues. This is also the case regarding union consultation.

The four assemblers have similar policies regarding the obligations of employers to consult unions over the utilization of precarious employment, 
including any plans by the companies to reduce the number of full-time positions as a proportion of the total workforce. However, there are disparities in the agreements concerning the companies' obligations to consult employees and their unions over redundancies. While Ford is only compelled to notify unions of any plans regarding retrenchments, GM-Holden's 2001 EBA states that it must "consult" with unions over such matters. Toyotas' past two agreements have stated that compulsory separation conditions would be subject to further negotiations with unions. However, the EBAs of Mitsubishi are silent on this issue. Nonetheless, issues relating to job security are likely to be a continuing source of conflict between employers and unions, with the unions attempting to maintain some uniformity for their members in this regard.

\section{SKILL FORMATION}

Issues relating to skill formation have become increasingly important in the auto assembly industry. A Vehicle Industry Certificate (VIC) was introduced as part of the award restructuring process in the late 1980s, which linked pay levels to skills and comprised different levels for production work and the maintenance trades. Skill formation is thus an issue that is dealt with by awards, not enterprise agreements, and because the benchmark for skills is an industry-wide certificate, there is little variation between the assemblers on this matter. The VIC encompassed both on and off the job training and was intended to provide automotive workers with a "portable" qualification that would enable them to move between employers within the industry and gain recognition for skills acquired. The VIC has been revised in recent years and is currently known as Certificate II. According to workers and managers, the majority of employees across all four assemblers have completed or are in the process of completing VIC/Certificate II training. The sentiment among union officials and shop-floor employees was that older workers were less enthusiastic than their younger counterparts about acquiring new skills through the VIC program.

There is a high degree of similarity between the automotive assemblers in regard to pay based on skills, with all four companies introducing different types of skills, qualification and training-related payments and allowances at various stages since the introduction of enterprise bargaining. In terms of training, however, there has been some variation between the auto assemblers. Mitsubishi is the only assembler that does not have any provisions relating to occupational-specific training in its EBAs, but this issue is outlined in other documents agreed to between the union and the company, thus demonstrating that agreements are not all-encompassing in regulating employment relations in the sector. There were also other 
forms of training, covering issues such as quality, production, maintenance and temporary labour, which were only provided by one of the assemblers.

\section{WAGES AND REMUNERATION}

The average wages of automotive assembly sector workers in Australia are 19 per cent higher those of the average manufacturing industry worker (Productivity Commission, 2002: 249). However, wages in the Australian automotive industry are well below those in other developed countries (see Table 5). Despite the advent of decentralized enterprise bargaining in 1991, it has taken some time for inter-firm wage variation to take effect and even now, there are similar wage rates for assembly workers across the industry. The main disparity is between the more profitable companies, such as Toyota and GM-Holden, and the less profitable, such as Mitsubishi, where a widening gap has begun to emerge since 1999. For example, in 2005 , a production worker at Toyota was paid a weekly wage of $\$ 808.79$, while a worker in the equivalent occupational grade at Mitsubishi received a weekly wage of $\$ 764.90$ (see Table 6).

TABLE 5

Comparison of the Average Net Hourly Earnings of Automotive Workers in Selected Developed Countries, 2003

\begin{tabular}{lcc}
\hline & Net wages (US\$) & $\begin{array}{c}\text { Net wages } \\
\text { ( }\end{array}$ \\
\hline Australia & 9.86 & 7.71 \\
Canada & 21.77 & 16.41 \\
Denmark & 29.63 & 20.69 \\
France & 15.66 & 10.74 \\
Germany & 35.97 & 28.41 \\
Great Britain & 17.64 & 11.37 \\
Japan & 20.26 & 10.09 \\
Republic of Korea & 9.40 & 6.89 \\
USA & 25.89 & 19.68 \\
\hline
\end{tabular}

Source: International Metalworkers Federation. 2004. The Purchasing Power of Working Time: An International Comparison. IMF: Geneva. 
TABLE 6

Weekly Wage Rates (\$A) for Australian Automotive Assembly Production Workers (selected years)

\begin{tabular}{lcccc}
\hline & Toyota & GM-Holden & Ford & Mitsubishi \\
\hline 1993 & $\$ 457.68$ & $\$ 445.30$ & $\$ 455.80$ & $\$ 449.20$ \\
1995 & $\$ 493.46$ & $\$ 491.20$ & $\$ 482.30$ & $\$ 483.50$ \\
1997 & $\$ 564.90$ & $\$ 549.30$ & $\$ 539.30$ & $\$ 540.70$ \\
1999 & $\$ 610.80$ & $\$ 608.50$ & $\$ 598.90$ & $\$ 593.50$ \\
2001 & $\$ 681.72$ & $\$ 659.80$ & $\$ 661.80$ & $\$ 635.70$ \\
2003 & $\$ 730.12$ & $\$ 737.40$ & $\$ 727.90$ & $\$ 696.20$ \\
2005 & $\$ 808.79$ & $\$ 809.13$ & $\$ 806.30$ & $\$ 764.30$ \\
\hline
\end{tabular}

NB: Rates are for the highest wage available to production operators and are consistent comparisons across all companies. Wage rates are applicable to those given to production operators on 1 January of each year.

The agreements and awards for all four automotive assemblers specify wage differentials to be paid to employees in accordance with their relevant occupational grade and as appropriate to their skills and occupation. Employees in all of the companies receive additional pay if they are in the process of undertaking or have completed the VIC. Where there have been changes to wage differentials, the variations have been minor. All of the automotive companies, with the exception of Mitsubishi, have certified at least one enterprise agreement containing performance-related remuneration provisions. However, such clauses have not always been effectively implemented. As previously noted (Lansbury and Baird, 2002: 111), experiments with performance-based pay or monetary bonus have generally been of a "short term nature and have failed due to perceptions of unfairness, poor management or corruption of the schemes".

All of the Ford enterprise agreements contain a merit allocation system for salaried employees whereby half of their potential salary increases were linked to the achievement of specific goals, work output, quality improvement, customer feedback and contribution to team work. Such a system does not apply to non-salaried employees, among whom levels of unionization are highest. This is because the unions are against a pay system that would potentially generate competition among employees. Similarly, the early Toyota EBAs contained performance-based pay components, which would be paid to employees upon the achievement of various productivity indicators. However, this system ceased to operate in 1994. Although none of the GM-Holden EBAs contained at-risk pay components, the 1992 
agreement provided for quarterly bonuses based on customer satisfaction. GM-Holden employees are given non-monetary rewards for the achievement of specified attendance targets and there are various targets for production output and quality, although these are not connected in any way to remuneration or any other rewards. These provisions are not specified in any GM-Holden agreement or award.

\section{ENTERPRISE GOVERNANCE}

One of the main changes since the introduction of enterprise bargaining has been the presence of clauses in agreements that affirm the commitment of the parties to the collective bargaining process. This became more important to the unions in the sector following the passage of the Workplace Relations Act 1996, which contained provisions for individual, non-union employment contracts, known as Australian Workplace Agreements (AWAs) that can replace awards and enterprise bargaining agreements, however only the Ford and GM-Holden EBAs specifically exclude the use of AWAs.

There are strong similarities between GM-Holden, Ford, Mitsubishi and Toyota regarding provisions contained in their EBAs that relate to union rights and responsibilities. When a provision is included in an EBA by one company, such provision will often "flow on" to other companies in the next round of bargaining. However, there is still some variation between the companies. Hence, although each of the current EBAs provide for the recognition by the company of unions, there is considerable divergence in the content of such clauses. In regard to the issue of right of entry for union officials, for example, there are differences between the four assemblers. Mitsubishi and Adecco have carefully phrased clauses which could be interpreted as placing greater restriction on officials, while Toyota and Ford are silent on the matter.

Despite the provisions contained in the various agreements, the AMWU claims that its officials have virtually unrestricted access to employees in the assembly plants. Yet according to some respondents in our interviews, Mitsubishi and GM-Holden are regarded as more accommodating as far as "right of entry" arrangements are concerned, in comparison with Ford and Toyota, where a 24-hour notice period is strictly enforced. However, union officials seeking access to Mitsubishi must comply with a code of conduct before entering the site. Unlike the other companies, recent Ford and GM-Holden agreements contain initiatives regarding special provisions for female union representatives, with Ford establishing a pilot program for female deputy shop stewards and GM-Holden allowing the establishment of two female deputy shop steward positions. 
All four auto companies have established workplace-based consultative mechanisms, such as plant consultative committees, to enable the parties to discuss a broad array of issues. According to industry representatives, these types of consultative mechanisms facilitate the most effective avenues of communication. Working parties and single-issue committees are often established to deal with transient or ad hoc issues. For example, Mitsubishi has established a "calendar committee" to deal with the rostering of days off, and the most recent Toyota agreement allows for a "problem resolution committee". Furthermore, although the companies apparently established non-trades and trades training committees as a result of the structural efficiency principle in the late 1980s, only Ford appears to have specifically affirmed the role of such committees in their EBAs. Such issues are now encompassed at GM-Holden through its state-based consultative committees. There are other consultation arrangements in place amongst the assemblers that are not captured in enterprise agreements. One example is work group meetings, which are held at the end of every shift at GM-Holden. Suggestion schemes have also been introduced at GM-Holden and Mitsubishi, with some success at both companies.

\section{DISCUSSION AND CONCLUSION}

To what degree has employment relations in the Australian auto assembly sector been influenced by the coexisting forces of globalization and enterprise bargaining? On the one hand, it might be expected that globalization will produce greater convergence amongst the four producers. On the other hand, enterprise based bargaining may facilitate increasing divergence between companies, and therefore contribute to more pronounced intra-industry variation. Furthermore, national institutional factors could be thought to mediate the influences of globalization and shape the nature of employment relations outcomes.

In terms of work organization, there has been a clear convergence around the concept, if not the practice, of lean production. Three of the four assemblers profess lean production strategies, however, consistent with the arguments of Kochan et al. (1997), there are differences in the extent to which lean production principles have been implemented and utilized by the four assemblers. This is evident in relation to teamwork, where considerable variation in the composition and purpose of teams is evident. In three of the four companies, staffing patterns have been reasonably resistant to change, with the full-time, permanent employment model being maintained by the union until very recently. It is at Mitsubishi, the poorest performer in the market, where the most marked staffing divergence has occurred, with the AMWU relinquishing permanence to agency hire in return for 
job and market security for the other employees. Skill formation reflects a strong sectoral influence, with common industry training standards and all companies paying according to skill. However, it is in total wage outcomes that another divergence occurs and again it is in Mitsubishi where the industry pattern breaks down. Enterprise bargaining outcomes for Mitsubishi employees started to fall away in the late 1990s and have not recovered to the levels of the other three companies. Finally, in terms of enterprise governance, again the union has maintained a reasonable consistent approach, although it is not always codified in the enterprise agreements in the same way.

Convergence has therefore occurred in production systems, skill formation and enterprise governance while divergence has emerged in remuneration and staffing practices between the four auto assemblers. Enterprise bargaining was anticipated to result in different employment relations outcomes yet, arguably, the influence of strong union organization has prevented greater variation between the companies. Locke (1992) argues that the historical and contextual diversity in which actors operate will result in different responses when presented with the same challenges. He emphasizes local socioeconomic conditions and the politics of strategic choice as important factors in determining the extent of intra-national, or in this case, intra-industry change. One state is home to the least successful company (Mitsubishi) and the second most effective (GM-Holden) in terms of market share, while the operations of the most successful (Toyota) and also the second least effective (Ford) are in another state suggests that local socioeconomic conditions may not be as significant a factor as is argued by Locke. Another factor that Locke attributes to variation, that may hold greater weight in explaining variation in the automotive employment relations, relates to the strategies available to the parties in alleviating market pressures.

Increased competition from overseas producers has been cited in support of employment relations reforms, but the direction this change has taken has been shaped by the decisions available to employers and unions. For example, employers in the sector do not appear to have strongly resisted the demands of unions regarding high wage claims (at least by Australian standards) in enterprise agreement negotiations. However, a trade-off for generous wage outcomes appears to have come in the form of greater numerical flexibility. Indeed, the use of precarious employment and provision for redundancy appears to be the main strategies that the companies have chosen to alleviate the competitive pressures that globalization has placed on Australian automotive assemblers.

While there are differences between the employment relations practices of the four assemblers, national-level institutional factors appear to have 
prevented greater divergence occurring. The residue of centralization, the strength of trade unions in the sector, and even bargaining coordination between employers, have resulted in the maintenance of continuity in relation to union recognition and support for trade union membership. There are also similarities between the companies in areas such as working hours, training and redundancy provisions.

The longer term future of the Australian automotive industry remains uncertain due to import competition, changes in government policies on tariff protection and fluctuations in the exchange rate of the Australian dollar, as well as whether globalize companies are willing to make longterm investments in the domestic automotive assembly sector. Given the small size of the Australian market, the long-term viability of the industry depends on the strategies adopted by the companies to produce vehicles of world-class quality and to win access to overseas markets for their products. As has been the case to date, enterprise bargaining will continue to be an important indicator of the extent that companies seek to integrate employment relations into such strategies. However, the continuing influence of national systems of employment relations in an increasingly globalize industry remains to be seen.

\section{REFERENCES}

BAmber, Greg and Russell D. LANSbury. 1997. "Employment Relations in the Australian Automotive Industry: A Question of Survival." Changing Employment Relations in Australia. Jim Kitay and Russell D. Lansbury, eds. Melbourne: Oxford University Press, 81-101.

BAMBER, Greg J., Russell D. LANSBURY and Nick WaILES. 2004. International and Comparative Employment Relations: Globalisation and the Developed Market Economies. Sydney: Allen and Unwin.

BRAY, Mark, Stephen DEERY, Janet WALSH and Peter WARING. 2005. Industrial Relations: A Contemporary Approach. Sydney: McGraw-Hill.

Bray, Mark and Peter WARING. 2005. "'Complexity' and 'Congruence' in Australian Labour Regulation.” Journal of Industrial Relations, 47 (1), $1-15$.

DEWR. 2002. Submission by the Department of Employment and Workplace Relations May 2002: Post 2005 Assistance Arrangements for the Automotive Manufacturing Sector - Productivity Commission's Automotive Industry Inquiry. Canberra: Department of Employment and Workplace Relations.

DISR. 2005. Automotive Industry Policy Fact Sheet. Canberra: Department of Industry, Science and Resources. Available at: http://www.disr.gov.au/ Access date: 11 August 2005.

Ellem, Bradon, Marian BaIRD, Rae CoOPER and Russell D. LANSBURY. 2005. "WorkChoices: Myth Making at Work." Journal of Australian Political Economy, 56, 13-31. 
KATZ, Harry and Owen DARBISHIRE. 2000. Converging Divergences: Worldwide Change in Employment Systems. Ithaca: ILR Press/Cornell University Press.

KerR, Clark, John T. Dunlop, Frederick H. Harbison and Charles A. Myers. 1960. Industrialism and Industrial Man: The Problems of Labour and Management in Economic Growth. London: Penguin.

Kitay, Jim and Russell D. Lansbury. 1997. The Changing Nature of Employment Relations in Australia. Melbourne: Oxford University Press.

Kochan, Thomas A., Russell D. Lansbury and John Paul MacDufFie. 1997. After Lean Production: Evolving Employment Practices in the World Auto Industry. Ithaca: ILR Press.

LANSBURY, Russell D. and Marian Baird. 2002. "Employment Relations and Restructuring of the Automotive Assembly Industry in Australia." Bulletin of Comparative Labour Relations, 45, 95-118.

LOCKE, Richard M. 1992. "The Demise of the National Union in Italy: Lessons for Comparative Industrial Relations Theory." Industrial and Labor Relations Review, 45 (2), 229-249.

MuraKami, Thomas. 1999. "Joint Committees on Teamwork in a British, German and Australian General Motors Plant." Labour and Industry, 10 (1), 107-125.

Productivity Commission. 1996. Automotive Case Study: Micro Reform Survey of Impacts on Firms, Report 96/17. Canberra: Australian Government Publishing Service.

Productivity Commission. 2002. Review of Automotive Assistance: Inquiry Report. Canberra: Commonwealth of Australia.

WaILES, Nick and Russell D. LANsBury. 1997. Flexibility vs. Collective Bargaining? Patterns of Australian Industrial Relations Reforms during the 1980s and 1990s. ACIRRT Working Paper No. 49. Sydney: Australian Centre for Industrial Relations Research and Training.

WomAcK, James P., Daniel T. JoNES and Daniel Roos. 1990. The Machine that Changed the World. New York: Rawson Associates.

\section{RÉSUMÉ}

\section{La négociation décentralisée dans une industrie qui se mondialise : le cas de l'industrie de l'automobile en Australie}

Cet essai cherche à vérifier de quelle façon le secteur de l'assemblage des automobiles en Australie a réagi à la double pression de la mondialisation croissante et de la négociation à l'échelle de l'entreprise. L'industrie de la fabrication automobile a joué un rôle majeur dans l'économie australienne et, de plus, elle représente l'une des industries d'importation les plus 
importantes. Le secteur inclut plusieurs centaines de fournisseurs de pièces et quatre constructeurs automobiles: Ford, GM-Holden, Mitsubishi et Toyota; les deux premiers sont de propriété américaine, alors que les deux derniers sont possédés par des Japonais. La nature compétitive croissante de l'industrie automobile à l'échelle mondiale, les profits qui s'effritent et une diminution du ratio des exportations sur les importations dans l'industrie australienne ont incité les gouvernements, les manufacturiers et les syndicats à concevoir des façons de rendre l'industrie plus efficace.

Un changement majeur qui a affecté l'industrie australienne de l'automobile au cours de la dernière décennie fut le glissement d'un système fortement centralisé de relations industrielles vers une forme plus décentralisée de négociation collective sur la base de l'entreprise. Cette dernière implique une négociation directe des conditions d'emploi et des salaires entre les employeurs et leurs employés, qui est officialisée par des conventions collectives à l'échelle de l'entreprise. Le caractère fortement syndiqué de l'industrie australienne de l'automobile implique que les syndicats négocient des ententes au nom des salariés non syndiqués dans l'entreprise.

D'un côté, on peut s'attendre à ce que la mondialisation introduise un degré de convergence plus élevé entre les manufacturiers. D'un autre côté, la négociation sur la base de l'entreprise peut entraîner une divergence plus grande entre les sociétés et, par conséquent, contribuer à une variation intraindustrie plus prononcée. De plus, des facteurs institutionnels nationaux peuvent être perçus comme un frein aux influences de la mondialisation et ils peuvent façonner la nature des résultats des relations du travail.

En termes d'organisation du travail, il existe une compréhension commune du concept, sinon de la pratique, de la production « allégée » (lean production). Trois des quatre constructeurs mettent de l'avant des stratégies de production allégée; cependant, il existe des différences en pratique quant à l'ampleur de l'application de ces principes chez les quatre constructeurs. C'est particulièrement le cas lorsqu'on considère le travail d'équipe, où les différences sont importantes au plan de la composition et des objectifs des équipes. Dans trois des quatre sociétés, les modes de dotation en personnel ont résisté au changement, en conservant le modèle de l'emploi permanent et à plein temps, maintenu en place par les syndicats jusqu'à récemment. C'est à la société Mitsubishi, l'acteur le plus pauvre dans ce marché, où la divergence la plus grande au plan de la dotation s'est produite, alors que les syndicats abandonnaient la permanence à une agence de recrutement en retour d'une sécurité d'emploi et de marché pour les autres employés.

La formation professionnelle reflète l'influence forte du secteur, avec des normes de formation communes pour l'industrie et des salaires payés par toutes les entreprises selon les compétences. Cependant, c'est au plan de la rémunération globale que d'autres différences se produisent et, 
encore là, c'est la société Mitsubishi qui fait bande à part. Les effets de la négociation à l'échelle de l'entreprise chez les salariés de Mitsubishi ont commencé à décliner vers la fin des années 1990 et ils ne sont pas revenus au niveau atteint par les trois autres sociétés. En termes de gouvernance d'entreprise, le syndicat a de nouveau maintenu une approche homogène et raisonnable, quoique cela n'apparaisse pas de la même manière dans les accords d'entreprise.

La convergence s'est donc produite dans les systèmes de production, dans la formation et dans la gouvernance d'entreprise, alors que la divergence entre les quatre constructeurs est apparue dans les pratiques de dotation et de rémunération. La concurrence accrue des compétiteurs d'outre-mer a été invoquée en guise de support aux réformes des relations du travail, mais la direction qu'a pris ce changement a été influencée par des décisions à la portée de la main des employeurs et des syndicats. En effet, le recours à l'emploi précaire et une disposition touchant l'excédent de main-d'œuvre sont devenues les principales stratégies retenues par les sociétés pour atténuer les pressions concurrentielles de la mondialisation sur les constructeurs d'automobiles en Australie. Alors que des différences persistent au plan des pratiques de relations du travail chez les quatre constructeurs, des facteurs d'ordre institutionnel à l'échelle du pays sont venus freiner l'apparition d'une divergence plus prononcée. Le reliquat de la centralisation, la force des syndicats du secteur et même une coordination des négociations chez les employeurs du secteur ont contribué au maintien d'une continuité eu égard à la reconnaissance syndicale et au support apporté au membership. Il existe également des similitudes entre les sociétés dans les domaines des heures de travail, de la formation professionnelle et des dispositions relatives au surplus de main-d'œuvre.

L'avenir à long terme de l'industrie de l'automobile en Australie demeure aléatoire, du à la concurrence de l'importation, à des changements dans la politique gouvernementale sur la protection des tarifs et aux fluctuations du taux de change du dollar australien. Également, l'incertitude persiste quant à savoir si les sociétés mondialisées sont disposées à investir en longue période dans le secteur domestique de l'automobile. Étant donné la petitesse du marché australien, la survie à long terme de l'industrie dépend aussi des stratégies mises de l'avant par les entreprises en vue de la production de véhicules de classe mondiale et pour l'obtention d'un accès aux marchés d'outre-mer pour leurs produits. Comme ce fut le cas à ce jour, la négociation sur la base de l'entreprise continuera à demeurer un indicateur du degré auquel les sociétés chercheront à intégrer les relations du travail à de telles stratégies. Cependant, l'influence persistante des systèmes nationaux de relations industrielles dans une industrie de plus en plus mondialisée demeure une inconnue. 